$\rightarrow$ The Dangers of Poetry $<$ 
This page intentionally left blank 


\section{THE DANGERS OF POETRY}

Culture, Politics, and Revolution in Iraq

KEVIN M. JONES 
Stanford University Press

Stanford, California

(C) 2020 by the Board of Trustees of the Leland Stanford Junior University. All rights reserved.

No part of this book may be reproduced or transmitted in any form or by any means, electronic or mechanical, including photocopying and recording, or in any information storage or retrieval system without the prior written permission of Stanford University Press.

Printed in the United States of America on acid-free, archival-quality paper

Library of Congress Cataloging-in-Publication Data

Names: Jones, Kevin M. (Kevin Michael), 1983-author.

Title: The dangers of poetry : culture, politics, and revolution in Iraq / Kevin M. Jones.

Description: Stanford, California : Stanford University Press, 2020. | Includes bibliographical references and index.

Identifiers: LCCN 2020008440 (print) | LCCN 202000844 I (ebook) | ISBN 978 I 5036r 3393 (cloth) | ISBN 978I 5036r3874 (ebook)

Subjects: LCSH: Political poetry, Arabic-Iraq-History and criticism. | Arabic poetry-2oth century-History and criticism. | Antiimperialist movements-Iraq-History. | Nationalism-Iraq-History. | Iraq-Politics and government-2oth century.

Classification: LCC PJ8040 .J66 2020 (print) | LCC PJ8040 (ebook) | DDC 892.7/16099567-de23

LC record available at https://lccn.loc.gov/2020008440

LC ebook record available at https://lccn.loc.gov/202000844I

Cover design: Rob Ehle

Cover image: Jawad Salim, cover illustration to Buland al-Haydari, Ji'tum ma al-Fajr (Baghdad: Matba at al-Rabita, I960). Background paper, iStock. 
For Kate and Zoey 
This page intentionally left blank 